\title{
縦平均流速算定式の精度について
}

\author{
正員春 日 屋

\section{ON THE ACCURACY OF THE CALCULATING FORMULAS FOR THE VERTICAL MEAN VELOCITY}

伸 莦*

by Nobumasa Kasugaya, C.E. Member

\section{Synopsis :}

The author, at first, theoretically argues about the accuracy of the calculating formulas for the vertical mean velocity, connecting them with the various theories with respect to the vertical velocity distribution in an open channel. Then, applying those formulas to the data obtained in the River Tone, he concludes that it is desirable to adopt the two-point method or the three-point new one, which is introduced by the mean value theorem, in the ordinary condition, and the four-point new method at the place where the flow is exceedingly turbulented. Among the formulas having prevailed up to this time, the three-point method and the fourpoint one except the two-point one are not valuable at all.

要 旨 本論文では, まず, 開水路の重西流速曲線に関する諸説と関連させて縦平均流速算定式の精度 そついて論じ, 次に, 利根川の実測值を基としてこれらを梌討し, 以上の結果から, 普通には 2 点法か 平均値 3 点法を, 流れが極端任乱ているところでね平均倠 4 点法を用いるべきで, 従来の諸式のうち, 3 点法, 4 点法は全く無価值であることを結論する。

\section{1. まえがき}

筆者は Gauss の平均值法を用い，縦平均流速算定式として，次の諸式を導いた ${ }^{1)}$ 。

2 点法: $v_{m}=\left(v_{0.211}+v_{0.789}\right) / 2 \div\left(v_{0.2}+v_{0.8}\right) / 2$

平均值 3 点法 : $v_{m}=\left\{5\left(v_{0.113}+v_{0.887}\right)+8 v_{0.500}\right\} / 18 \cdots$

平均值 4 点法 : $v_{m}=0.174\left(v_{0.069}+v_{0.931}\right)+0.326\left(v_{0.330}+v_{0.670}\right)$

ここに, $v_{m}$ は垂直線にそつての縦平均流速， $v_{0.211}$ は水表面から水深の 2 割 1 分 1 厘の点での流速を表わし, 他も同様である。（1）式は従来の 2 点法と同じもので垂直流速世線の次数が高々 3 次までは䛣差をともなわない

（今までは 2 次式まで詋差をともなわないと考光られていた）。(2) 式招よび (3) 式は従来の 3 点法招よび 4 点法 の公式とは異なつたもので，これらを従来の公式と区別するため，こんご平均值 3 点法括よび平均值 4 点法とょ ぶこととしよう。これらの公式は垂直流速曲線の次数がそれぞれ高々 5 次招よび 7 次のときに 誤差をともなわな いことが証明される。

さて, 従来の縦平均流速算定式のうち， 3 点法と 4 点法とは㳄のと括りである ( 2 点法は上の (1) 式である)。

3 点法: $v_{m}=\left(v_{0.2}+2 v_{0.6}+v_{0.8}\right) / 4$

4 点法 : $v_{m}=\left\{(3 / 2) v_{0.2}+v_{0.4}+v_{0.6}+(5 / 4) v_{0.8}\right\} / 5$

このほか, 水表面から水深の 6 割の点での流速をるつて縦平均流速とする 1 点法や垂直流速曲線法などがある。 本論文では, まず, 垂直流速曲線式に関する従来の諸説を考察しつつ種々な縦平均流速算定式との関連性につ いて解説し, 次に利根川に挌ける実測例に適用しててれら算定式の精度を検討し, 最後に, 從来の算定式に含ま れている定係数を理論的に修正すれば精度が改善されることに言及する。

\section{2. 垂直流速曲線式に関する諸説と縦平均流速算定式との関連性}

縦平均流速算定式が垂直流速曲線の形状と密接な関係のあることはいうまでもない。開水路に捛ける垂直流速 曲線の形状についての実験的または理論的研究は古くより種々㧍こなわれ, 多くの垂直流速曲線式が与兄られた 2) 6)。古くは Du Buat の直線式, Woltmann 叉 Eytelwein の, 流速 0 の点に頂点をもち垂直線を軸とする放物 線式がある。おた, Funk は対数曲線で, Gerstner は楕円曲線で, Weisbach や Lahmeyer は值線で表わされ。 ると主張した。Darcy-Bazin は表面に水平軸を有する放物線式注実験結果から誘導し，Harder は最大流速の生

* 中央大学助教授, 工学部土木工学教室 
じる位置で共通接線をもつ 2 つの棈円曲線を用い, Lipke は最大流速の 生じる位置より上は楕円下は放物線とし, Kozeny は楕円分布を提唱し た。また, Humphreys-Abbot Mississippi 河での実測結果より水表 面下に最大流速を有する 2 次放物線式を発表した。これと対し, Hagen は実験式として鉛直軸をるち頂点を床上飞有する放物線式を主張し, Jasmund は鉛直軸を有する対数曲線式を仮定し Elbe 河々括讨実測 の結果と一致することを確かめた。そのほか, Kaplan や Lavale の指 数公式がある。

日本では，速水頌一郎教授”が Gebelein の 2 平行板内の乱れの下半

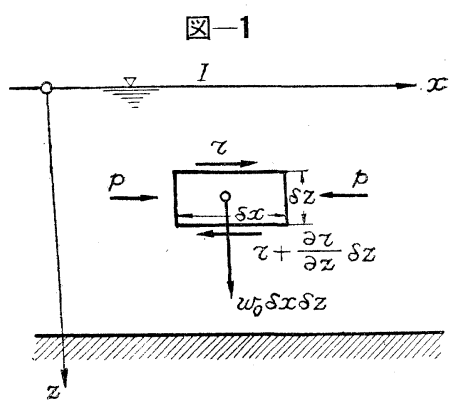
分定開水路飞用いた理論式を示され，安芸資一教授 ${ }^{8}$ は洞動粘性係数を 深さに無関係な定数と仮定して, 最大流速の位置の割合 $\alpha$, 水深 $h$, 水面勾配 $I$, Chèzy の係数 $C$ を含む 2 次式を 誘導され，久宝保教授 ${ }^{9}$ は最大流速の位置飞捛いて乱れの混合距離を一定とし末たこの位置の上下に执いて流速分 布を対称であると仮定して， $\alpha, h, I$ 拓よび粗度係数 $n$ を含む逆双曲正弦曲線式を導かれた。

筆者柱, 次飞述べるようと, 最大流速の位置の割合 $\alpha$, 表面流速と縦平均流速との比 $k$ 招よび縦平均流速 $v_{m}$ を含む 2 次式を解析的飞誘導した。すなわち，図一1 亿示すように，開水路の等流飞执いて流れの方向に $x$ 軸を 深さにそつて $z$ 軸をとり, 流れの中に幅が単位長さの微小体 $\delta x \delta z$ を考光る。 $z$ 点での乱れによるセン応力を とし， $x$ 方向の力の釣合を考学ると，上下流面に垂直に㗢く力 $p \delta z$ は相殺されるから，けつきよく，次の式が成。 り立つ。

$$
\tau \delta x-\{\tau+(\partial \tau / \partial z) \delta z\} \delta x+w_{0} \delta x \delta z \cdot I=0
$$

ここに, $w_{0}$ は水の単位容積の重量, $I$ は水面勾配である。上の式から,

$$
\partial \tau / \partial z=w_{0} I \cdots
$$

がえられるから，これを $z$ K関して1度積分すれば，積分定数を $c$ として，

$$
\tau=w_{0} I z+c \cdots
$$

ここで, 河底 $z=h$ そ招けるセン応力を $\tau_{0}$ とすれば,

$$
c=\tau_{0}-w_{0} I h
$$

これを(c) 式に入れれば，

$$
\tau=w_{0} I(z-h)+\tau_{0}
$$

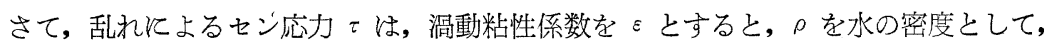

$$
\tau=-\rho \varepsilon(d v / d z)
$$

で表わされるから，この関係を（e）式に入れると， $g$ を重力加速度として，

$$
\varepsilon(d v / d z)=g I(h-z)-\left(\tau_{0} / \rho\right)
$$

いま, 最大流速の位置の割合凹を考学る。この

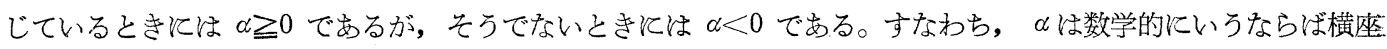

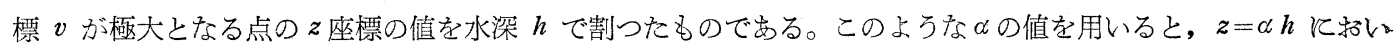
て $d v / d z=0$ であるから，(g) 式より，

$$
\tau_{0} / \rho=g h I(1-\alpha) \text {. }
$$

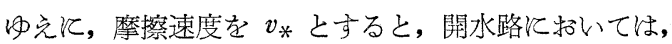

$$
v_{*}=\sqrt{\tau_{0} / \rho}=\sqrt{g h I(1-\alpha)} \text {. }
$$

摩擦速度を $v_{*}=\sqrt{g h I}$ とするのは， $\alpha=0$ すなわち最大流速が水表面と括いて生じているときであつて，一般 には (i) 式のように表わされる。

さて，(h) 式を（g）式に入れると，次の式が光られる。

$$
\varepsilon(d v / d z)=g h I\{\alpha-(z / h)\} \cdots
$$

（j）式を解くためには，をが $z$ のどのような函数で表わされるかを知らなければならないが，この理論的な函数 形は目下のところ不明というほかはない。Boussinesq はこれを深さに無関係な定数であるといい, Krey は深さ そつれて放物線的に変化すると述べているが ${ }^{10)}$, Kozeny ${ }^{11)}$ 々 Donau 河の実測值から, 大体江いて, の減少函数で $\varepsilon=K /\{a-(\boldsymbol{z} / h)\}$ で表わされると主張した。ここに, $K$ は河底粗度や河底流速によつて変わるが $\boldsymbol{z}$

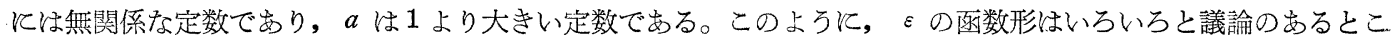
ろであるから，い末，一般江 $z$ の函数として（j）式を $z$ に関して積分すると， 


$$
v=g h I\left(\alpha \int \frac{1}{\varepsilon} d z-\frac{1}{h} \int \frac{z}{\varepsilon} d z\right)
$$

(k) 式より明らかなように，を字 Boussinesq などのように定数と仮定すれば垂直流速曲線な 2 次式となり， Kozeny の式を採用すれば 3 次式となる。いま， 8 を定数と仮吴する場合の重直流速曲線式を誘導しよう。(k) 式 より，cを積分定数として,

$$
v=(g h I / \varepsilon)\left\{\alpha z-\left(z^{2} / 2 h\right)\right\}+c
$$

表面流速を $v_{s}$ とすれば， $c=v_{s}$ となるから（1）式は，

$$
v=v_{s}+(g h I / \varepsilon)\left\{\alpha z-\left(z^{2} / 2 h\right)\right\} .
$$

ここで, 縦平均流速 $v_{m}$ を導入すると,

$$
v_{m}=\frac{1}{h} \int_{0}^{h} v d z=v_{s}+\frac{g I}{\varepsilon}\left(-\frac{\alpha h^{2}}{2}-\frac{h^{2}}{6}\right)=v_{s}-\frac{g I}{6 \varepsilon}(1-3 \alpha) h^{2} .
$$

中えに，(n) 式より渦動粘性係数 $\varepsilon$ は,

$$
\varepsilon=g I(1-3 \alpha) h^{2} /\left\{6\left(v_{s}-v_{m}\right)\right\} \text {. }
$$

（o）式を（m) 式に入れて をを消去すると容易に次の式が光られる。

$$
v=\left(v_{m} / p\right)\left\{p k+2 \alpha(z / h)-(z / h)^{2}\right\}
$$

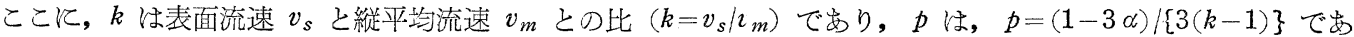
る。

さて（6）式は垂直流速曲線を軸が水平な 2 次放物線であそと仮定して誘導した従来の諸公式のすべてを含さ ものである。例えば, Bazin の公式 ${ }^{12)}$,

$$
v=v_{s}-24(z / h)^{2} \sqrt{h I}=v_{m}+\left\{8-24(z / h)^{2}\right\} \sqrt{h I}
$$

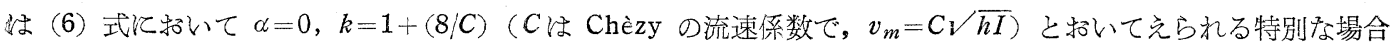
である。 $\alpha=0$ は放物線の軸が水表面に存在するとの仮定であり, 後者の関係は $C=30 \sim 50$ とすることによつて $k=1.16 \sim 1.27$ となることを示す。

Boussinesq の公式 ${ }^{13)}$,

$$
v=v_{m}\left[1+(a / 3 C)\left\{(1 / 3)-(z / h)^{2}\right\}\right] \text { ( } a: \text { 定数) }
$$

は（6）式扮いて $\alpha=0, p=3 C / a$ と招いて光られる。後者の式より $k=1+a /(9 C)$ となるから(Bazin の公式 恃 $a=72$ としたもの)， $a / C=0.8 \sim 2.7$ ( $a=40 \sim 80, C=30 \sim 50)$ とすることによつて $k=1.10$ 1.30 となる。

Humphreys-Abbot の公式 ${ }^{14)}$,

$$
\begin{aligned}
& v=v_{\max }-\left(0.28 v_{m} / \sqrt{h+0.46}\right)^{0.5}\left\{\left(\boldsymbol{z}-\boldsymbol{z}_{0}\right) / h\right\}^{2} \\
& \left(v_{\max } \text { : 最大流速, } z_{0}:\right. \text { 最大流速の生じている点の深さ) }
\end{aligned}
$$

恃（6）式に拾いて $p=\left(\sqrt{h+0.46} v_{m} / 0.28\right)^{0.5}$ と特いて兄らる。なぜならば, Humphreys-Abbot の公式に 招いて $z_{0} / h=\alpha$ と特けば,

$$
\begin{aligned}
v=v_{\max } & -\left(0.28 v_{m} / \sqrt{h+0.46}\right)^{0.5} \alpha^{2}+2 \alpha\left(0.28 v_{m} / \sqrt{h+0.46}\right)^{0.5}(z / h) \\
& -\left(0.28 v_{m} / \sqrt{h+0.46}\right)^{0.5}(z / h)^{2}
\end{aligned}
$$

これと（6）式とを比較して，

$$
\begin{aligned}
& k=\left(v_{\max } / v_{m}\right)-\left\{0.28 /\left(\sqrt{h+0.46} v_{m}\right)\right\}^{0.5} \alpha^{2} \\
& p=\left(\sqrt{h+0.46} v_{m} / 0.28\right)^{0.5}
\end{aligned}
$$

肪ららるが，前者の関係は後者の関係が成声していれば当然成り立つことが次のようにして証明される。すな

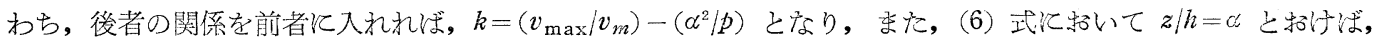
$v_{\max } / v_{m}=\left(p k+\alpha^{2}\right) / p$ がえられるからである。

安芸教授の公式 ${ }^{15)}$,

$$
v=\left\{C+(20 / 3)-20 \alpha+40 \alpha(z / h)-20(z / h)^{2}\right\} / \overline{h I}
$$

は (6) 式に特いて $p=20 / C$ と招いてえられる。すなわち， $k=1+\{(1-3 \alpha) C / 60\}$ である。安芸教授は $\alpha=0.0$ 〜0.3 と考えて招られるから，C=30〜50 とすれば $k=1.08 〜 1.83$ となる。

以上のように, Bazin, Boussinesq, Humphreys-Abbot, 安芸教授の諸公式はすべて（6）式の特別な場合であ ることが明らかとなつた。すなわら，(6) 式に招ける 2 つの゚ラメーター $k$ と とをを適当に規定することによつ ていずれかの公式が党られるのである。筆者浪このパラメーターに影響を及ぼす因子を, 河底粗度, 水深, 水面

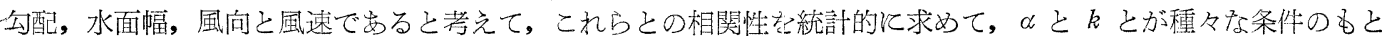


そ扔いて最大の確率をるつて生じるときの值を求めた ${ }^{16), 17) 。 ~}$

さて, 垂直流速曲線の解析的な理論《しばらく括いて, 縦平均流速の測定といろ問影に限るならば, 2 点法の

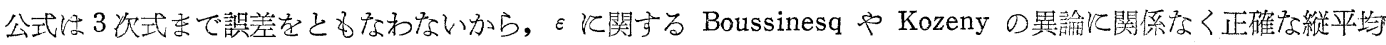
流速を求めることができる。

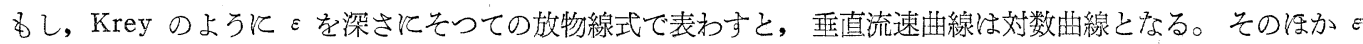
が $z$ に関する他の函数形をとる場合には，(k) 式の右辺の積分は $z$ の有理整式とならないのが一般であるが，(j)

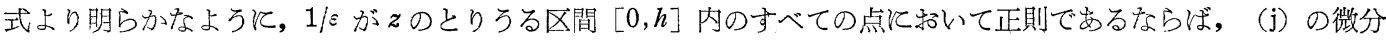
方程式の解子すべての点で正則となるから，（j）式は次の形の級数解をるつ。

$$
v=C_{0}+C_{1}(z / h)+C_{2}(z / h)^{2}+C_{3}(z / h)^{3}+\cdots \cdots \cdots
$$

したがつて，この場合にも $(z / h)^{4}$ 以上の項を省略すれば 2 点法を用いて，また $(z / h)^{6}$ 以上の項を省略すれば 平均值 3 点法を用いて，それぞれ縦平均流速の近似值を求めることができる。

次に，垂直流速曲線に関する対数曲線式について触れて抏こう。

Prandtl 招よび Kármán そよる運動量輸送理論から円管内の流速分布曲線が誘導され，実験結果ときわめてよ く一致した。 M.P.O'Brien, G.H. Keulegan その他の人々によつてこの公式の開水路への拡張が試みられたが, V.A.Vanoni ${ }^{18)}$ もとの 1 人で, これを幅 $2.77 \mathrm{ft}$, 深さ $0.59 \mathrm{ft}$ の矩形水路の中央での流速分布にあてはめてよい 一致を示したと述べ， 2 割と 8 割との流速の平均が 6 割の点での流速にはぼ一致することにより対数曲線説を支 持している。円管内での流速分布を水路に拡張した式は ${ }^{19)}$,

$$
v=v_{\max }+\left(v_{*} / \kappa\right) \ln \{1-(z / h)\} \text {. }
$$

ここに， $\kappa$ は普遍定数で円管に対しては $\kappa \doteqdot 0.40$ であるが，E.H. Taylor ${ }^{20)}$ は開水路に関する Bazin の実験值 に照合させて， は開水路の形状によつて異なることを認め，採用した実験例の範囲では $\kappa=0.22 \sim 0.43$ であつ たと述べている。

（7）式では，v は水表面に近づくにつれて大きくなり，最大流速は水表面に拈いて生じることる仅定している。 ところで, $0 \leqq z / h<1$ であるから，(7) 式の右辺の自然対数は $z / h$ のベキ級数に展開され，縦平均流速の測定に 招いて，2点法招よび平均值 3 点法を用いれば，展開式のそれぞれ $(z / h)^{4}$ 括よび $(z / h)^{6}$ 以上の項を省略したと きの近似值を求めることとなる。この場合の誤差はそれぞれ次のようになる。

(7) 式に掠ける縦平均流速 $v_{m}$ は,

$$
v_{m}=\frac{1}{h} \int_{0}^{h} v d z=v_{\max }+\frac{v_{*}}{\kappa h} \int_{0}^{h} \ln \left(1-\frac{z}{h}\right) d z=v_{\max }-\frac{v_{*}}{\kappa}
$$

（p）式を（7）式に入れることにより，縦平均流速の位置の割合は 0.632 となることがわかる。

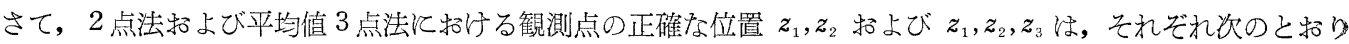
である ${ }^{21)}$

2 点法 : $z_{1} / h=(1-\sqrt{1 / 3}) / 2 \div 0.211, z_{2} / h=(1+\sqrt{1 / 3}) / 2 \div 0.789$

平均值 3 点法 : $z_{1} / h=(1-\sqrt{3 / 5}) / 2 \div 0.113, z_{2} / h=1 / 2=0.500$,

$$
z_{3} / h=(1+\sqrt{3 / 5}) / 2 \div 0.887
$$

そこで，2点法に和いて，観測点 $z_{1}, z_{2}$ に和村る流速をそれぞれ $v_{1}, v_{2}$ とすると，

$$
v_{1}=v_{\max }+\left(v_{*} / \kappa\right) \ln \{(1+\sqrt{1 / 3}) / 2\}, v_{2}=v_{\max }+\left(v_{*} / \kappa\right) \ln \{(1-\sqrt{1 / 3}) / 2\}
$$

ゆえに，(1) 式の右辺の值は，

$$
\left(v_{1}+v_{2}\right) / 2=v_{\max }+(1 / 2)\left(v_{*} / \kappa\right) \ln \{(1 / 4)-(1 / 12)\}=v_{\max }-0.89588\left(v_{*} / \kappa\right) \ldots
$$

したがつて，このときの誤差 $E_{2}$ は，

$$
E_{2}=\left\{\left(v_{1}+v_{2}\right) / 2\right\}-v_{m}=0.10412\left(v_{*} / \kappa\right)
$$

平均值 3 点法に和いては，上と同じ記号を用いると，

$$
\begin{aligned}
& v_{1}=v_{\max }+\left(v_{*} / \kappa\right) \ln \{(1+\sqrt{3 / 5}) / 2\}, v_{2}=v_{\max }+\left(v_{*} / \kappa\right) \ln (1 / 2), \\
& v_{3}=v_{\max }+\left(v_{*} / \kappa\right) \ln \{(1-\sqrt{3 / 5}) / 2\} .
\end{aligned}
$$

ゆえに，(2) 式の右辺の值は，

$$
\begin{aligned}
& \left\{5\left(v_{1}+v_{3}\right)+8 v_{2}\right\} / 18=v_{\max }+(5 / 18)\left(v_{*} / \kappa\right) \ln \left[\{(1 / 4)-(3 / 20)\}(1 / 2)^{8 / 5}\right] \\
& =v_{\max }-0.94768\left(v_{*} / \kappa\right)
\end{aligned}
$$

したがつて，このときの誤差 $E_{3}$ は，

$$
E_{3}=\left[\left\{5\left(v_{1}+v_{3}\right)+8 v_{2}\right\} / 18\right]-v_{m}=0.05232\left(v_{*} / \kappa\right)
$$


$\therefore E_{3} / E_{2}=0.50$

もし, 従来の 3 点法の, (4) 式を用いれば, 誤差 $E^{\prime}{ }_{3}$ は,

$E^{\prime}{ }_{3}=0.08371\left(v_{*} / \kappa\right)$

$\therefore E_{3} / E_{3}{ }^{\prime}=0.62$

すなわち, 垂直流速分布が対数曲線で表わされるならば, 2 点法, 3 点法, 平均值 3 点法の誤差はいずれる正 となり，乙か子平均值 3 点法の誤差は 2 点法のそれの半分， 3 焦法のそれの約 6 割に過ぎない。この結論ね，対 数曲線式の定数項を $A\left[(7)\right.$ 式では $\left.v_{\text {max }}\right]$ 招よび対数項の定係数を $B\left[(7)\right.$ 式では $\left.v_{*} / \kappa\right]$ とするとき， $A, B$ がどのようなパラメーターを含んでいても全く同じであることは上の計算過程から明らかである。

現在，開水路の垂直流速曲線式㣙ては，水表面下ある位置に水平軸をるつた 2 次放物線説之鉛直軸をるつ た対数曲線説とがその主流をなしているといわれる22)。対数曲線説は，その起源より考えて，底面に近い部分に おいては実情に即しているが，水表面にまでこれを搪張することは，最大流速が水表面よりも下方と生じている 自然河川の実情から考光ても無理なように思われる。しかし，鼠大流速の位置の割合 $\alpha$ は，実験水路の上うに水 面幅がきわめて狭く水深が浅くしかも粗度を大きくしたような場合には，負の值をとるものである。すなおち， 実験水路に括ける垂直流速分布はしばしば対数曲線に近似する。このような場合には 2 点法の半分の誤差しかも たない平均值 3 点法が特に有效であろう。2 次放物線説が自然河川の流れの中央部に括いて最もよく適合するこ とは，すで筆者も述べたと招りである ${ }^{23)}$ 。とより，垂直流速分布が 2 次放物線であるというのは平均的なる のであつて，実際の分布はるつと次数の高い曲線であると考光方方が，流速測定の場合には殊飞安全である。そ こで, 次には実例について, 縦平均流速算定式の精度について㯕討してみよう。

\section{3. 平均值法公式亡従来の公式との精度の比較}

まず, 自然河川の中央部にめつて流れが整正な場合につき, 徐来の縦平均流速算定式すなわち 1 点法, 2 点法, 3 点法, 4 点法と平均值 3 点法との精度を比較するため, 次の資料を使用する。

昭和 28 年 10 月上り昭和 30 年 1 月に至る間, 関東地方建設局利根川上流工事々務所が栗橋地先の低水流量測 定筒所に扔いて実測した全資料より 20 個を抽出し，1つの資料より 1 本の垂直流速曲線をとる。選ばれる垂直流 速曲線は，河川の中央部に位して両岸からの 2 次流の影響をなるべく受けず，水深が $1.00 \mathrm{~m}$ 以上のものとする。 流速分布は 20 30 cm 間隔の垂直流速曲線法飞よよつて定められ，観測流速は $1 \mathrm{~cm} / \mathrm{sec}$ 単位で与えられている。 諸公式に必要な観測点での流速は垂直流速曲線のグラフ上より䛃みとられる $(5 \mathrm{~mm} / \mathrm{sec}$ 単位)。計算の結果を表 -1 亿示寸。表中の $\alpha$ は最大流速の位置の割合， $\beta$ は縦平均流造の位置の割合を表わし，縦平均流速 $v_{m}$ の值は 垂直流速曲線法によつて求めた值 '(垂直流隩曲線と縦軸と水表面 抢よび 河底とで囲まれた面積を方眼紙上より求 めて水深 $h$ で割る）であり，諸公式による計算值の下のカッコおの值は，上の $v_{m}$ 亿対する各計算值の誤差を百 分率で示したるのである。表中の修正 3 点法, 修正 4 点法については後で述べる。

表一1 より明らかなようと，1点法飞招ける詋差の絶対值の最大は $5.7 \%$, 詋差の絶対值が $1.0 \%$ を越す例は 14 例である。2 点法ではこれらの值はそれぞれ $2.9 \%$ 招よび 4 例, 3 点法では $4.3 \%$ 㧍よび 7 例, 4 点法では $3.3 \%$ 打よび 15 例である。平均值 3 点法に执いては, 誤差の浥対值の最大は $1.4 \%$ (資料番号 8 ) であつて他 の 19 例の誤差はその絶対值がずて 1.0\%より小さくこのうち5 例では全く諤差が認められなからた。この ように, 從来の諸公式の中では ( 1 点法を除く), 2 点法の精度が最もよく, 3 点法がこれにつぎ, 4 点法は最も 劣る。平均值 3 点法は 2 点法の半分以下の誤差しかるたず，最も優れていることがわかる。

上の 20 例は, 垂直流速曲線の形状が 2 次放物線に近似していると思われる資料についてのものであつた。しか し, 相当乱れた分布を示す曲線とついては, 諸公式の優劣は異なつた結果を示すか子知れない。一体, 従来の 3 点法は, 河底が非常に粗いか水草に覆われるかして流速分布が乱れていると考光られる場合に 適用されるべく考 案されたもので，このような場合には分布を2 次式と考光て誘導した 2 点法では 8 割の点での流速が特に乱れて

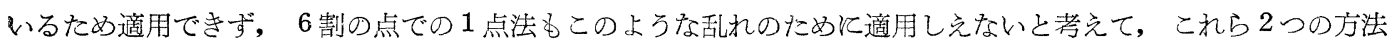
の結果の算術平均をるつて縦平均流速としょうとするるのである ${ }^{24)}$ 。

極端に乱れた流速分布に対して諸公式の精度学検討するため, 杭打水制間での実測資料を用いる。これは昭和 27 年 12 月 17 日执よび 18 日に, 関東地方建設局利根川上流工事々務所が樋ノ口地先の杭打水制（末口 $15 \mathrm{~cm}$, 長さ $6 \mathrm{~m}$ ) 間と招いて垂直流速曲線法（観測点間の間隔は $30 \mathrm{~cm}$ ）を用いて流速分布と縦平均流速とを求めたも

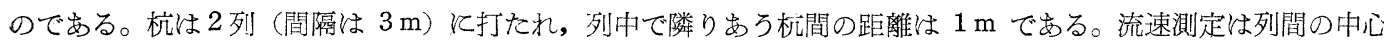
線にそい $50 \mathrm{~cm}$ 間隔で招こなわれた。観測流速は $1 \mathrm{~mm} / \mathrm{sec}$ 采で求められ，流速分布は図一2 亿示すように相当 な乱れを呈している。表一 2 は従来の諸公式と平均值 3 点法扔占び平均值 4 点法とによる計算値とその誤差とを 
図-2
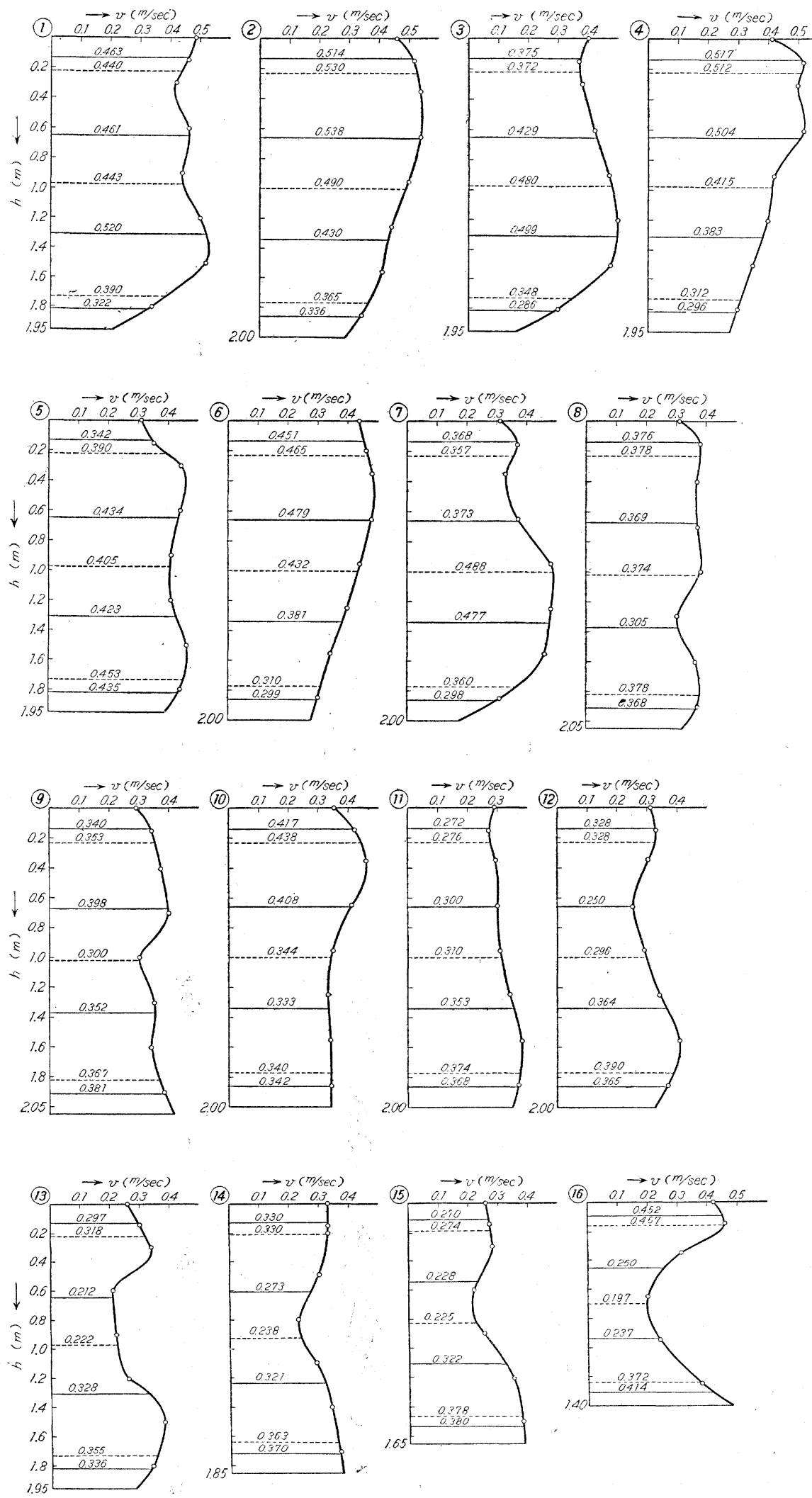
表一1

\begin{tabular}{|c|c|c|c|c|c|c|c|c|c|c|c|c|}
\hline 坆料 & $\begin{array}{l}\text { 测 定 } \\
\text { 年月昌 }\end{array}$ & $\left|\begin{array}{c}\text { 水深 } h \\
(\mathrm{~m})\end{array}\right|$ & $\alpha$ & $\beta$ & $\begin{array}{l}\text { 經平均流 } \\
\text { 速 } v_{m} \\
(\mathrm{~m} / \mathrm{sec})\end{array}$ & I点法 & 2 点法 & 3 点法 & 4 点法 & 平均值 3 点法 & 修正 3 点法 & 修正 4 点法 \\
\hline 1 & 28.10 .18 & 2.05 & 0.244 & 0.663 & 0.672 & $\begin{array}{c}0.710 \\
(+5.7 \%)\end{array}$ & $\begin{array}{c}0.670 \\
(-0.3 \%)\end{array}$ & $\begin{array}{c}0.690 \\
(+2.7 \%)\end{array}$ & $\begin{array}{c}0.668 \\
(-0.6 \%)\end{array}$ & $\begin{array}{c}0.671 \\
(-0.1 \%)\end{array}$ & $\begin{array}{c}0.676 \\
(+0.6 \%)\end{array}$ & $\begin{array}{c}0.675 \\
(+0.4 \%)\end{array}$ \\
\hline 2 & 28.10 .27 & 1.85 & 0.189 & 0.605 & 0.719 & $\begin{array}{c}0.720 \\
(+0.1 \%)\end{array}$ & $\begin{array}{c}0.718 \\
(-0.1 \%)\end{array}$ & $\begin{array}{c}0.719 \\
( \pm 0.0 \%)\end{array}$ & $\begin{array}{c}0.706 \\
(-1.8 \%)\end{array}$ & $\begin{array}{c}0.720 \\
(+0.1 \%)\end{array}$ & $\begin{array}{c}0.721 \\
(+0.3 \%)\end{array}$ & $\begin{array}{c}0.721 \\
(+0.3 \%)\end{array}$ \\
\hline 3 & 28.11 .12 & 1.35 & 0.237 & 0.600 & 0.669 & $\begin{array}{c}0.670 \\
(+0.1 \%)\end{array}$ & $\left(\begin{array}{c}0.665 \\
-0.4 \%)\end{array}\right.$ & $\begin{array}{c}0.668 \\
(-0.1 \%)\end{array}$ & $\begin{array}{c}0.651 \\
(-2.7 \%)\end{array}$ & $\begin{array}{c}0.669 \\
( \pm 0.0 \%)\end{array}$ & $\begin{array}{c}0.668 \\
(-0.1 \%)\end{array}$ & $\begin{array}{c}0.668 \\
(-0.1 \%)\end{array}$ \\
\hline 4 & $28.11 .27 \mid$ & 1.75 & 0.200 & 0.623 & 0.547 & $\begin{array}{c}0.555 \\
(+1.5 \%)\end{array}$ & $\begin{array}{c}0.552 \\
(+0.9 \%)\end{array}$ & $\begin{array}{c}0.554 \\
(+1.3 \%)\end{array}$ & $\begin{array}{c}0.543 \\
(-1.1 \%)\end{array}$ & $\begin{array}{c}0.550 \\
(+0.5 \%)\end{array}$ & $\begin{array}{c}0.555 \\
(+1.5 \%)\end{array}$ & $\begin{array}{c}0.555 \\
(+1.5 \%)\end{array}$ \\
\hline 5 & 28.12 .17 & 1.40 & 0.314 & 0.636 & 0.644 & $\begin{array}{c}0.660 \\
(+2.5 \%)\end{array}$ & $\left(\begin{array}{c}0.642 \\
(-0.3 \%)\end{array}\right.$ & $\begin{array}{c}0.651 \\
(+1.1 \%)\end{array}$ & $\begin{array}{c}0.632 \\
(-1.9 \%)\end{array}$ & $\begin{array}{c}0.643 \\
(-0.2 \%)\end{array}$ & $\begin{array}{c}0.646 \\
(+0.3 \%)\end{array}$ & $\begin{array}{c}0.646 \\
(+0.3 \%)\end{array}$ \\
\hline 6 & 29. 1.22 & 1.00 & 0.220 & 0.600 & 0.770 & $\begin{array}{c}0.770 \\
( \pm 0.0 \%)\end{array}$ & $\begin{array}{c}0.775 \\
(+0.6 \%)\end{array}$ & $\begin{array}{c}0.772 \\
(+0.3 \%)\end{array}$ & $\begin{array}{c}0.760 \\
(-1.3 \%)\end{array}$ & $\begin{array}{c}0.770 \\
( \pm 0.0 \%)\end{array}$ & $\begin{array}{c}0.778 \\
(+1.0 \%)\end{array}$ & $\begin{array}{c}0.779 \\
(+1.2 \%)\end{array}$ \\
\hline 7 & 29.2 .20 & 1.05 & 0.267 & 0.667 & 0.728 & $\begin{array}{c}0.740 \\
(+1.6 \%)\end{array}$ & $\begin{array}{c}0.725 \\
(-0.4 \%)\end{array}$ & $\begin{array}{c}0.732 \\
(+0.5 \%)\end{array}$ & $\begin{array}{c}0.703 \\
(-3.0 \%)\end{array}$ & $\begin{array}{c}0.728 \\
( \pm 0.0 \%)\end{array}$ & $\begin{array}{c}0 \\
(+0\end{array}$ & $\begin{array}{c}0.728 \\
( \pm 0.0 \%)\end{array}$ \\
\hline 8 & $29 \cdot 3 \cdot 10 \mid$ & 2.25 & 0.267 & 0.618 & 0.762 & $\begin{array}{c}0.770 \\
(+1.0 \%)\end{array}$ & $\begin{array}{c}0.755 \\
(-0.9 \%)\end{array}$ & $\begin{array}{c}0.762 \\
( \pm 0.0 \%)\end{array}$ & $\begin{array}{c}0.756 \\
(-0.8 \%)\end{array}$ & $\begin{array}{c}0.751 \\
(-1.4 \%)\end{array}$ & $\begin{array}{c}0.760 \\
(-0.3 \%)\end{array}$ & $\begin{array}{c}0.762 \\
( \pm 0.0 \%)\end{array}$ \\
\hline 9 & 29.3 .19 & 1.05 & 0.286 & 0.657 & 0.692 & $\begin{array}{c}0.720 \\
(+4.0 \%)\end{array}$ & $\begin{array}{c}0.685 \\
(-1.0 \%)\end{array}$ & $\begin{array}{c}0.702 \\
(+4.3 \%)\end{array}$ & $\begin{array}{c}0.680 \\
(-1.7 \%)\end{array}$ & $\begin{array}{c}0.689 \\
(-0.4 \%)\end{array}$ & $\begin{array}{c}0.691 \\
(-0.1 \%)\end{array}$ & $\begin{array}{c}0.690 \\
(-0.3 \%)\end{array}$ \\
\hline 10 & 29. 4.28 & 1.85 & 0.270 & 0.638 & 0.753 & $\begin{array}{c}0.780 \\
(+3.6 \%)\end{array}$ & $\begin{array}{c}0.758 \\
(+0.7 \%)\end{array}$ & $\begin{array}{c}0.769 \\
(+2.1 \%)\end{array}$ & $\begin{array}{c}0.752 \\
(-0.1 \%)\end{array}$ & $\left(\begin{array}{c}0.749 \\
(-0.5 \%)\end{array}\right.$ & $\begin{array}{c}0.763 \\
(+1.3 \%)\end{array}$ & $\begin{array}{c}0.763 \\
(+1.3 \%)\end{array}$ \\
\hline 11 & 29.5 .17 & 2.15 & 0.302 & 0.651 & 0.678 & $\begin{array}{c}0.710 \\
(+4.7 \%)\end{array}$ & $\begin{array}{c}0.698 \\
(+2.9 \%)\end{array}$ & $\begin{array}{c}0.704 \\
(+3.8 \%)\end{array}$ & $\begin{array}{c}0.687 \\
(+1.3 \%)\end{array}$ & $\begin{array}{c}0.682 \\
(+0.6 \%)\end{array}$ & $\begin{array}{c}0.701 \\
(+3.4 \%)\end{array}$ & $\begin{array}{c}0.701 \\
(+3.4 \%)\end{array}$ \\
\hline 12 & $29 \cdot 5.28$ & 1.50 & 0.200 & 0.607 & 0.742 & $\begin{array}{c}0.740 \\
(-0.3 \%)\end{array}$ & $\begin{array}{c}0.750 \\
(+1.1 \%)\end{array}$ & $\begin{array}{c}0.745 \\
(+0.4 \%)\end{array}$ & $\begin{array}{c}0.730 \\
(-1.6 \%)\end{array}$ & $\begin{array}{c}0.743 \\
(+0.1 \%)\end{array}$ & $\begin{array}{c}0.752 \\
(+1.3 \%)\end{array}$ & $\begin{array}{c}0.752 \\
(+1.3 \%)\end{array}$ \\
\hline 13 & $|29.8 .7|$ & 1.55 & 0.245 & 0.626 & 0.734 & $\begin{array}{c}0.740 \\
(+0.8 \%)\end{array}$ & $\begin{array}{c}0.735 \\
(+0.1 \%)\end{array}$ & $\begin{array}{c}0.738 \\
(+0.5 \%)\end{array}$ & $\begin{array}{c}0.721 \\
(-1.8 \%)\end{array}$ & $\begin{array}{c}0.730 \\
(-0.5 \%)\end{array}$ & $\begin{array}{c}0.738 \\
(+0.5 \%)\end{array}$ & $\begin{array}{c}0.739 \\
(+0.7 \%)\end{array}$ \\
\hline 14 & 29.8 .26 & 1.55 & 0.194 & 0.574 & 0.687 & $\begin{array}{c}0.670 \\
(-2.5 \%)\end{array}$ & $\begin{array}{c}0.695 \\
(+1.2 \%)\end{array}$ & $\begin{array}{c}0.682 \\
(-0.7 \%)\end{array}$ & $\begin{array}{c}0.686 \\
(-0.1 \%)\end{array}$ & $\begin{array}{c}0.687 \\
( \pm 0.0 \%)\end{array}$ & $\begin{array}{c}0.698 \\
(+1.3 \%)\end{array}$ & $\begin{array}{c}0.698 \\
(+1.3 \%)\end{array}$ \\
\hline 15 & 29.10 .14 & 1.80 & 0.289 & 0.633 & 0.761 & $\begin{array}{c}0.780 \\
(+2.5 \%)\end{array}$ & $\begin{array}{c}0.755 \\
(-0.8 \%)\end{array}$ & $\begin{array}{c}0.768 \\
(+0.9 \%)\end{array}$ & $\begin{array}{c}0.750 \\
(-1.4 \%)\end{array}$ & $\begin{array}{c}0.765 \\
(+0.4 \%)\end{array}$ & $\begin{array}{c}0.760 \\
(-0.1 \%)\end{array}$ & $\begin{array}{c}0.761 \\
( \pm 0.0 \%)\end{array}$ \\
\hline 16 & 29.10 .30 & 1.20 & 0.300 & 0.658 & 0.819 & $\begin{array}{c}0.850 \\
(+3.8 \%)\end{array}$ & $\begin{array}{c}0.815 \\
(-0.5 \%)\end{array}$ & $\begin{array}{c}0.832 \\
(+1.6 \%)\end{array}$ & $\left(\begin{array}{c}0.809 \\
(-1.2 \%)\end{array}\right.$ & $\begin{array}{c}0.819 \\
( \pm 0.0 \%)\end{array}$ & $\begin{array}{c}0.821 \\
(+0.2 \%)\end{array}$ & $\begin{array}{c}0.821 \\
(+0.2 \%)\end{array}$ \\
\hline 17 & 29.12 .4 & 1.55 & 0.129 & 0.587 & 0.679 & $\begin{array}{c}0.670 \\
(-1.3 \%)\end{array}$ & $\begin{array}{c}0.678 \\
(-0.1 \%)\end{array}$ & $\begin{array}{c}0.674 \\
(-0.7 \%)\end{array}$ & $\begin{array}{c}0.662 \\
(-2.5 \%)\end{array}$ & $\begin{array}{c}0.682 \\
(+0.4 \%)\end{array}$ & $\begin{array}{c}0.680 \\
(+0.1 \%)\end{array}$ & $\begin{array}{c}0.680 \\
(+0.1 \%)\end{array}$ \\
\hline 18 & 29.12 .22 & 1.15 & 0.235 & 0.652 & 0.696 & $\begin{array}{c}0.710 \\
(+2.0 \%)\end{array}$ & $\begin{array}{c}0.695 \\
(-0.2 \%)\end{array}$ & $\begin{array}{c}0.702 \\
(+0.9 \%)\end{array}$ & $\begin{array}{c}0.680 \\
(-2.3 \%)\end{array}$ & $\begin{array}{c}0.698 \\
(+0.3 \%)\end{array}$ & $\begin{array}{c}0.698 \\
(+0.3 \%)\end{array}$ & $\begin{array}{c}0.698 \\
(+0.3 \%)\end{array}$ \\
\hline 19 & 30.1 .13 & 1.10 & 0.164 & 0.591 & 0.704 & $\begin{array}{c}0.700 \\
(-0.6 \%)\end{array}$ & $\begin{array}{c}0.705 \\
(+0.1 \%)\end{array}$ & $\begin{array}{c}0.702 \\
(-0.3 \%)\end{array}$ & $\begin{array}{c}0.681 \\
(-3.3 \%)\end{array}$ & $\begin{array}{c}0.705 \\
(+0.1 \%)\end{array}$ & $\begin{array}{c}0.706 \\
(+0.3 \%)\end{array}$ & $\begin{array}{c}0.707 \\
(+0.4 \%)\end{array}$ \\
\hline 20 & $30.1 .25 \mid$ & 1.05 & 0.190 & 0.581 & 0.671 & $\begin{array}{c}0.660 \\
(-1.6 \%)\end{array}$ & $\begin{array}{c}0.675 \\
(+0.6 \%) \\
\end{array}$ & $\begin{array}{c}0.668 \\
(-0.4 \%) \\
\end{array}$ & $\begin{array}{c}0.674 \\
(+0.4 \%)\end{array}$ & $\begin{array}{c}0.672 \\
(+0.1 \%)\end{array}$ & $\begin{array}{c}0.676 \\
(+0.7 \%) \\
\end{array}$ & $\begin{array}{c}0.677 \\
(+0.9 \%)\end{array}$ \\
\hline \multirow{2}{*}{\multicolumn{6}{|c|}{$\begin{array}{l}\text { 䛠 差 の相 加 平 均 } \bar{E} \\
\text { 詔差の絶対值の相加平均 }|\bar{E}|\end{array}$}} & $+1.4 \%$ & $+0.2 \%$ & $+0.9 \%$ & $-1.4 \%$ & $-0.0 \%$ & $+0.6 \%$ & $+0.7 \%$ \\
\hline & & & & & & $2.0 \%$ & $0.7 \%$ & $1.1 \%$ & $1.5 \%$ & $0.3 \%$ & $0.7 \%$ & $0.7 \%$ \\
\hline
\end{tabular}

示したものである。表一2 の結果が示すように，極端に乱れた流速分布に対しては 2 点法は最も大きな誤差を与 え, 3 点法, 4 点法は少しながら改良された值を与光るが，いずれも適用しうるほど正確ではない。平均值 3 点 法でもこの場合には不十分で平均值 4 点法を用いれば誤差の絶対值の平均は $2.0 \%$ 以下となる。

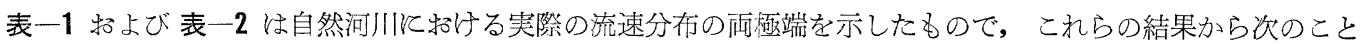
が結論される。従来の諸公式では 2 点法が最もよく, 3 点法, 4 点法は流速分布が乱れ 2 点法が相当な誤差を旺 するにつれて幾分よい結果を与えるようであるが，到底正確な公式ということはできない。平均值 3 点法は普通 程度の乱れに対しても十分安全に使用しうる最も優れた方法である。しかし，密に打たれた杭打水制間のように 極端な乱れがある場合には平均值 4 点法を使用する方が安全で別る。

われわれは，流量測定に際してなるべく少ない観測点で正確な值をうるのでなければならない。多くの観測点 をとればとるほど正確な值が光られると思うのは誤りである。なぜならば，観測時間中の水位の变動（したがつ て，流量の変化）飞よる影響を小さくするためと各観測点での測定時間を短くすれば，流れの眽動とよつて各点 での正確な流速が兄られず，これを長くして脈動の影響を免れようとすると全観測時間が娫長されて水位の変動 が影響するようになる。ゆ兄に，流量測定に招ける課題は，全観測点数をできるだけ少なくして各観測点での測 定時間をできるだけ長く（3 分以上が望ましい）することである年)。本論文では 垂直線とそつての縦平均流速し たがつて水面幅とそつての単位幅当りの流量を最少の観測点数でなるべく正確測定する方法を述べたのである。 水面幅にそつてとるべき重直線の本数とその位置就よび流量算定式については次の論文にゆずることとする。

\section{4. 従来の縦平均流速算定式の修正}

前節に招いて明らかなように，流れの中央部で流速分布が余り乱れていない普通の場合に從来の諸公式を適用 すると， 3 点法，4 点法は観測点数が多いにもかかわらずその精度は 2 点法に劣る。これは，観測流速に乗じる 定係数が不適当だからである。本節では，これら公式中の定係数学修正することにより，従来上りも正確と思わ 
表一2

\begin{tabular}{|c|c|c|c|c|c|c|c|}
\hline 資料番号| & $\begin{array}{c}\text { 水 深 } h \\
(\mathrm{~m})\end{array}$ & $\mid$\begin{tabular}{|l|} 
縦平均流速 \\
$v_{m}(\mathrm{~m} / \mathrm{sec})$
\end{tabular} & 2 点法 & 3 点 法 & 4 点法 & 平均値 3 点法 & 平均値 4 点法 \\
\hline 1 & 1.95 & 0.446 & $\begin{array}{c}0.456 \\
(+2.2 \%)\end{array}$ & $\begin{array}{c}0.475 \\
(+6.5 \%)\end{array}$ & $\begin{array}{c}0.438 \\
(-1.8 \%)\end{array}$ & $\begin{array}{c}0.427 \\
(-4.3 \%)\end{array}$ & $\begin{array}{c}0.456 \\
(+2.2 \%)\end{array}$ \\
\hline 2 & 2.00 & 0.465 & $\begin{array}{c}0.472 \\
(+1.5 \%)\end{array}$ & $\begin{array}{c}0.461 \\
(-0.9 \%)\end{array}$ & $\begin{array}{c}0.457 \\
(-1.7 \%)\end{array}$ & $\begin{array}{c}0.466 \\
(+0.2 \%)\end{array}$ & $\begin{array}{c}0.463 \\
(-0.4 \%)\end{array}$ \\
\hline 3 & 1.95 & 0.418 & $\begin{array}{c}0.421 \\
(+0.7 \%) .\end{array}$ & $\begin{array}{c}0.459 \\
(+9.8 \%)\end{array}$ & $\begin{array}{c}0.420 \\
(+0.5 \%)\end{array}$ & $\begin{array}{c}0.413 \\
(-1.2 \%)\end{array}$ & $\begin{array}{c}0.418 \\
( \pm 0.0 \%)\end{array}$ \\
\hline 4 & 1.95 & 0.420 & $\begin{array}{c}0.425 \\
(+1.2 \%)\end{array}$ & $\begin{array}{c}0.414 \\
(-1.4 \%)\end{array}$ & $\begin{array}{c}0.410 \\
(-2.4 \%)\end{array}$ & $\begin{array}{c}0.413 \\
(-1.7 \%)\end{array}$ & $\begin{array}{c}0.431 \\
(+2.6 \%)\end{array}$ \\
\hline 5 & 1.95 & 0.423 & $\begin{array}{c}0.462 \\
(+9.2 \%)\end{array}$ & $\begin{array}{c}0.435 \\
(+2.8 \%)\end{array}$ & $\begin{array}{c}0.419 \\
(-0.9 \%)\end{array}$ & $\begin{array}{c}0.414 \\
(-2.1 \%)\end{array}$ & $\begin{array}{c}0.415 \\
(-1.9 \%)\end{array}$ \\
\hline 6 & 2.00 & 0.412 & $\begin{array}{c}0.410 \\
(-0.5 \%)\end{array}$ & $\begin{array}{c}0.408 \\
(-1.0 \%)\end{array}$ & $\begin{array}{c}0.403 \\
(-2.2 \%)\end{array}$ & $\begin{array}{c}0.407 \\
(-1.2 \%)\end{array}$ & $\begin{array}{c}0.411 \\
(-0.2 \%)\end{array}$ \\
\hline 7 & 2.00 & 0.398 & $\begin{array}{c}0.389 \\
(-2.3 \%)\end{array}$ & $\begin{array}{c}0.436 \\
(+9.5 \%)\end{array}$ & $\begin{array}{c}0.393 \\
(-1.3 \%)\end{array}$ & $\begin{array}{c}0.416 \\
(+4.5 \%)\end{array}$ & $\begin{array}{c}0.393 \\
(-1.3 \%)\end{array}$ \\
\hline 8 & 2.05 & 0.359 & $\begin{array}{c}0.368 \\
(+2.5 \%)\end{array}$ & $\begin{array}{c}0.342 \\
(-4.7 \%)\end{array}$ & $\begin{array}{c}0.342 \\
(-4.7 \%)\end{array}$ & $\begin{array}{c}0.376 \\
(+4.7 \%)\end{array}$ & $\begin{array}{c}0.349 \\
(-2.8 \%)\end{array}$ \\
\hline 9 & 2.05 & 0.355 & $\begin{array}{c}0.358 \\
(+0.8 \%)\end{array}$ & $\begin{array}{c}0.351 \\
(-1.1 \%)\end{array}$ & $\begin{array}{c}0.351 \\
(-1.1 \%)\end{array}$ & $\begin{array}{c}0.333 \\
(-6.2 \%)\end{array}$ & $\begin{array}{c}0.370 \\
(+4.2 \%)\end{array}$ \\
\hline 10 & 2.00 & 0.374 & $\begin{array}{c}0.400 \\
(+7.0 \%)\end{array}$ & $\begin{array}{c}0.361 \\
(-3.5 \%)\end{array}$ & $\begin{array}{c}0.363 \\
(-2.9 \%)\end{array}$ & $\begin{array}{c}0.369 \\
(-1.3 \%)\end{array}$ & $\begin{array}{c}0.374 \\
( \pm 0.0 \%)\end{array}$ \\
\hline 11 & 2.00 & 0.325 & $\begin{array}{c}0.338 \\
(+4.0 \%)\end{array}$ & $\begin{array}{c}0.336 \\
(+3.4 \%)\end{array}$ & $\begin{array}{c}0.311 \\
(-4.3 \%)\end{array}$ & $\begin{array}{c}0.318 \\
(-2.2 \%)\end{array}$ & $\begin{array}{c}0.324 \\
(-0.3 \%)\end{array}$ \\
\hline 12 & 2.00 & 0.326 & $\begin{array}{c}0.351 \\
(+7.7 \%)\end{array}$ & $\begin{array}{c}0.340 \\
(+4.3 \%)\end{array}$ & $\begin{array}{c}0.309 \\
(-5.2 \%)\end{array}$ & $\begin{array}{c}0.331 \\
(+1.5 \%)\end{array}$ & $\begin{array}{c}0.321 \\
(-1.5 \%)\end{array}$ \\
\hline 13 & 1.95 & 0.290 & $\begin{array}{c}0.354 \\
(+22.1 \%)\end{array}$ & $\begin{array}{c}0.301 \\
(+3.8 \%)\end{array}$ & $\begin{array}{c}0.286 \\
(-1.4 \%)\end{array}$ & $\begin{array}{c}0.286 \\
(-1.4 \%)\end{array}$ & $\begin{array}{c}0.286 \\
(-1.4 \%)\end{array}$ \\
\hline 14 & 1.85 & 0.310 & $\begin{array}{c}0.334 \\
(+7.7 \%)\end{array}$ & $\begin{array}{c}0.313 \\
(+1.0 \%)\end{array}$ & $\begin{array}{c}0.289 \\
(-6.8 \%)\end{array}$ & $\begin{array}{c}0.298 \\
(-3.9 \%)\end{array}$ & $\begin{array}{c}0.315 \\
(+1.6 \%)\end{array}$ \\
\hline 15 & 1.65 & 0.292 & $\begin{array}{c}0.322 \\
(+10.3 \%)\end{array}$ & $\begin{array}{c}0.303 \\
(+2.8 \%)\end{array}$ & $\begin{array}{c}0.274 \\
(-6.2 \%)\end{array}$ & $\begin{array}{c}0.282 \\
(-3.4 \%)\end{array}$ & $\begin{array}{c}0.292 \\
( \pm 0.0 \%)\end{array}$ \\
\hline 16 & 1.40 & 0.312 & $\begin{array}{c}0.342 \\
(+9.6 \%)\end{array}$ & $(-11.9 \%)$ & $\begin{array}{c}0.275 \\
(-11.9 \%)\end{array}$ & $\begin{array}{c}0.290 \\
(-7.1 \%)\end{array}$ & $\begin{array}{c}0.309 \\
(-1.0 \%)\end{array}$ \\
\hline \multicolumn{3}{|c|}{$\begin{array}{l}\text { 誤差 の 相 加 平 均 } \bar{E} \\
\text { 誤差の絶対值の相加平均 }|\bar{E}|\end{array}$} & $\begin{array}{r}+5.2 \% \\
5.6 \%\end{array}$ & $\begin{array}{r}+1.3 \% \\
4.3 \%\end{array}$ & $\begin{array}{r}-3.4 \% \\
3.5 \%\end{array}$ & $\begin{array}{r}-1.6 \% \\
2.9 \%\end{array}$ & $\begin{array}{r}-0.0 \% \\
1.3 \%\end{array}$ \\
\hline
\end{tabular}

れる公式を導く。そうすれば，すでに光られている観測流速をとのまま用いて結果を修正することができるであ ろろ。しかし，修正された公式がはたして 2 点法より精度がよいかどうか問題で，もし精度が優れていなけれ ば， 6 割や 4 割の点での既往の観測值を捨て，2 割と 8 割の点での観測值だけから 2 点法で計算すればよい。

平均值法の原理 $\left.{ }^{26}\right)$ は, 区間 $[-1,1]$ 亿括いて変数 $t$ 亿関する連続函数のこの区間での平均值 $M$ が, この区 間内に適当にとつた $n$ 個の $t$ の值 $t_{i}$ 亿対する函数值 $y_{i}$ と $n$ 個の定係数 $R_{i}$ との積 $R_{i} y_{i}$ の総和に近似的に等し くなるように，すなわら，次の式が近似的飞成り立つよう飞， $t_{i}$ 扔よび $R_{i}$ の值を定めようとするるのである。

$$
M=R_{1} y_{1}+R_{2} y_{2}+\cdots \cdots+R_{n} y_{n} \cdots
$$

$2 n$ 個の根 $t_{i} ， R_{i}$ を定めるための連立方程式は次のようとなることが証明される。

$$
\begin{array}{ll}
R_{1}+R_{2}+\cdots \cdots+R_{n}=1, & R_{1} t_{1}+R_{2} t_{2}+\cdots \cdots+R_{n} t_{n}=0 \\
R_{1} t_{1}{ }^{2}+R_{2} t_{2}{ }^{2}+\cdots \cdots+R_{n} t_{n}{ }^{2}=1 / 3, & R_{1} t_{1}{ }^{3}+R_{2} t_{2}{ }^{3}+\cdots \cdots+R_{n} t_{n}{ }^{3}=0
\end{array}
$$

さて, 3 点法の公式は,

$$
v_{m}=\left(v_{0.2}+2 v_{0.6}+v_{0.8}\right) / 4=(1 / 4) v_{0.2}+(1 / 2) v_{0.6}+(1 / 4) v_{0.8}
$$

であるが，観測点の位置はとの末まとて定係数を修正した式を上の（a）式のようそ，

$$
v_{m}=R_{1} v_{0.2}+R_{2} v_{0.6}+R_{3} v_{0.8}
$$

と書いて, $R_{1}, R_{2}, R_{3}$ の值を（b) 式より求めればよい。(c) 式は座標点 $z_{1}, z_{2}, z_{3}$ をあらかじめそれぞれ $0.2 h$, $0.6 h, 0.8 h$ と選兀で, 定係数だけを未知数とした場合である。さて，変数 $z$ は区間 $[0, h]$ で定義されているか ら, $t=2(z / h)-1$ 亿よつて区間 $[-1,1]$ で定義される変数 $t$ 飞変換すれば,

$$
t_{1}=2\left(z_{1} / h\right)-1=-0.6, t_{2}=2\left(z_{2} / h\right)-1=0.2, t_{3}=2\left(z_{3} / h\right)-1=0.6 \text {. }
$$

ゆえに，末知数 $R_{1}, R_{2}, R_{3}$ を定めるための連立方程式は (b) 式に (d) の值を入れて,

$$
R_{1}+R_{2}+R_{3}=1, \quad-0.6 R_{1}+0.2 R_{2}+0.6 R_{3}=0,0.36 R_{1}+0.04 R_{2}+0.36 R_{3}=1 / 3 \text {. }
$$

(e) の連立方程式を解けば, $R_{1}=17 / 36, R_{2}=1 / 12, R_{3}=4 / 9$ となるから, 修正 3 点法の公式は次の上うになる。

$$
v_{m}=\left(17 v_{0.2}+3 v_{0.6}+16 v_{0.8}\right) / 36
$$

(11) 式が誤差をともなわないための垂直流速曲線の最高次数は 2 次である。なぜならば，(b) 式の初めから 3 つの式までを成立させて 4 番目の式すなわち $t$ 亿関する 3 次の式を成立させていないからである。 
同じょうとして, 修正 4 点法の公式 (誤差をとるなわないための垂直流速曲線の最高次数は 3 次) を求めると,

$$
v_{m}=\left\{11\left(v_{0.2}+v_{0.8}\right)+\left(v_{0.4}+v_{0.6}\right)\right\} / 24 \text {. }
$$

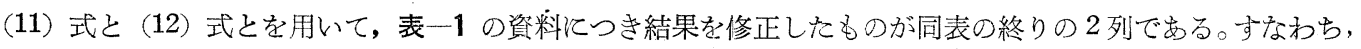
修正された公式を用いれば誤差は著しく小さくなり，3点法てついては従来の公式で誤差の絶対値が $2.0 \%$ を越

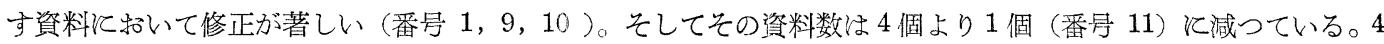
点法についても浪涪同じで, 修正の著しいものは番号 3，5，7，17，18，19であり，修正後誤差の絶対值が $2.0 \%$ を越す例は 1 個（番号11）あるに過ぎない。こころで，誤差の絶対值平均をみると，修正された両方法はいずれ も 2 点法と同じ精度である。このことは，4 割招よび 6 割の点での観測值は全く不要で， 2 割， 8 割の点での観 測值だけを用い 2 点法より計算すればよいことを示している。すなわち, 従来の 3 点法, 4 点法は全く無価值な 公式であり，4割，6割の点での観測值を入れることねよつで悪い結果を与兄ていると結論される。

な特， 2 点法の正確な公式比いては，観測点の位置は $0.211 h, 0.789 h$ である。これらをそれぞれ $0.2 h$ ， $0.8 h$ とすることは, 平均值法の原理からい光ば精度を犠牲にすることになる。 3 点法や 4 点法の修正式の諗導と 同じよう飞して，2つの観測点を $z_{1}=0.2 h\left(t_{2}=-0.6\right), z_{2}=0.8 h\left(t_{2}=0.6\right)$ 飞固定し，(b) 式より定係数 $R_{1}, R_{2}$

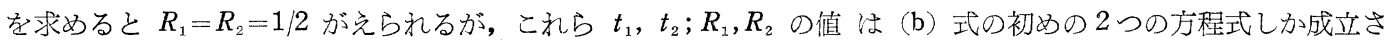
せず， 3 番目の式， $t_{1}{ }^{2} R_{1}+t_{2}{ }^{2} R_{2}=1 / 3$ を成立させない。すなわち, 2 割, 8 割の点での流速の相加平均をるつて 縦平均流速とするという簡易化された 2 点法は, 理論的に流速分布が 1 次式の場合にしか正確な值を与えないこ ととなり，3 次式まで誤差のない正確な 2 点法の公式にくらべて余りにも精度が劣る。ゆえに，水深が浅いとき には簡易化された式を用いてもよいが，水深が大きいときにほ正確な観測点をとることが望まれる。

\section{5. 結 語}

（1）開水路の垂直流速曲線については，佩動粘性係数を深さのどのような函数と仮定するかてよつて種々な理 諭式が兄られるが，筆者はこれを深さ無関係な定数と仮定して, Bazin, Boussinesq, Humphreys-Abbot, 安芸 教授の諸公式を包含する 2 次放物線式を誘導する。

(2) 縦平均流速の測定という問題に限るならば, 垂直流速分布に関する 2 次放物線説や対数曲線説のいかんに かかわらず，平均值法より誘導された 2 点法，平均值 3 点法はいずれる合理的である。対数分布に対しては平均 值 3 点法の誤差は 2 点法のそれの半分である。

（3）縦平均流速算定式に関する従来の諸公式と平均值法公式とを利根川の資料に適用して流れが整正な場合に は 2 点法または平均值 3 点法を, 杭打水制聞のように極端な乱れのある場合には平均值 4 点法を用いればよいこ とが示される。従来の 3 点法, 4 点法はいずれの場合にもよい結果を与光ない。

（4）従来の 3 点法，4点法がよい結果を与先ない原因は，観測流速に乗じる係数が合理的でないからで，平均 值法の原理に基づいてこの係数を修正すれば，結果を著しく改善することができるが，その精度は 2 点法のそれ を出ない。これより，水深の 4 割，6 割の点での観測流速をむちこむことは無意味であることが結諭される。

終りに貴重な資料を提供していただいた建設省利根川上流工事々務所に対し深甚な謝意を表する次第である。

\section{参考文献}

1）春日屋伸昌：平均値法による流量算定式について, 土木学会誌, 第 38 巻, 第 7 号, 1953, p. $17 \sim$ p. 21 .

2）土木学会：水理公式集，1949, p. 1 p. 2.3 3) 物部長穂: 水理学 (增補改訂版), 1954, p. 104 p. 106.

4) 安芸瞻一: 流量測定法, 1954, p. $46 \sim$ p. 49 . 5) 狩野德太郎: 農業水利, 1949, p. $47 \sim$ p. 49 .

6) Rouse, H.: Fluid mechanics for hydraulic engineers, 1938, p. 274 p. 275.

7) Hayami, S.: On the mechanics of flow in a wide alluvial river, Journ. of the Shanghai Science Insti., Section 1 , Vol. 1, July, 1939, p. 239 p. 261.

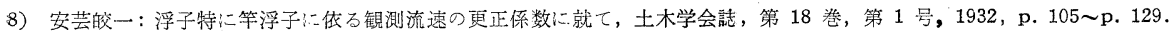

9）久宝 保: 開水路に沶什る乱流の縦平均流速分布について, 土木学会誌, 第 35 巻, 第 7 号, 1950, p. 9 p. 13.

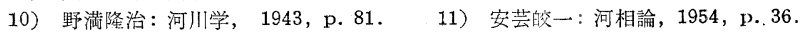

12) 土木学会: 水理公式集, 1949, p. 1.13 13) 本間 伿: 水理学, 1939, p. 120 .

14) 土木学会: 水理公式集, 1949 , p. 1 p. 2 . 15) 京左, p. 12 p. 13 .

16）春日屋伸昌：開水路の垂直流速曲線に㧍什る平均流速の位置の分布性について，土木学会誌，第 40 巻, 第 5 号, 1955, p. $24 \sim$ p. 29 .

17）春日屋伸昌：開水路の垂直流速曲線に及涹寸諸因子間の相関性について，土木学会誌，第 40 巻，第 10 号， 1955, p. $44 \sim$ p. 51 .

18) Vanoni, V.A.: Velocity distribution in open channels, Civil Eng., Vol. 11, 1941, p. 356 p. 357.

19) 佐藤清一: 水理学 (下巻), 1955, p. 81.

20) Taylor, E.H.: Velocity distribution in open channels, Trans. A.G.U., 1939, p. 641 p. 643.

21) 春日屋伸昌：平均值法の原理と流量測定への応炤，中央大学 70 周年記念工学部論交集, 1955, p. $57 \sim$ p. 74 .

22) 宮本武之輔: 治水工学, 1953, p. 85.

23）春日屋伸昌：開水路仁技计る垂直流速曲線沪ついて，士木学会誌，第 38 巻，第 9 号，1953，p. 15 p. 20 .

24) Grover, N.C. and Harrington, A.W.: Stream flow, 1949, p. 250.

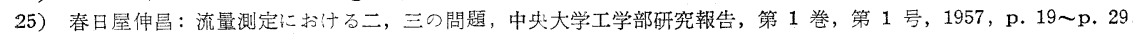

26）春日屋伸昌：最小 2 乘法と実験式, 応用数学講座, 第 5 巻, 第 2 部, 1957, p. $296 \sim$ p. 300 . 